\title{
Seizure evoked regulation of LIM-HD genes and co-factors in the postnatal and adult hippocampus [version 1; peer review:
}

\section{2 approved]}

\author{
Vanisha Lakhina1,2, Lakshmi Subramanian 1,3, Dhananjay Huilgol1,4, \\ Ashwin S Shetty ${ }^{1}$, Vidita A. Vaidya1, Shubha Tole ${ }^{1}$ \\ ${ }^{1}$ Department of Biological Sciences, Tata Institute of Fundamental Research, Mumbai, India \\ ${ }^{2}$ Current affiliation: Lewis Sigler Institute for Integrative Genomics, Princeton University, NJ, USA \\ ${ }^{3}$ Current affiliation: Department of Neurology, University of California, San Francisco, CA, USA \\ ${ }^{4}$ Current affiliation: Cold Spring Harbor Laboratory, NY, USA
}

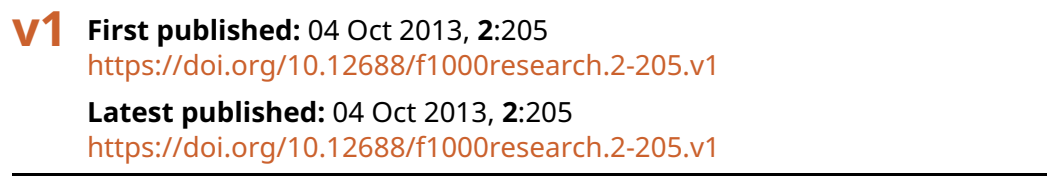

\section{Abstract}

The LIM-homeodomain (LIM-HD) family of transcription factors is well known for its functions during several developmental processes including cell fate specification, cell migration and axon guidance, and its members play fundamental roles in hippocampal development. The hippocampus is a structure that displays striking activity dependent plasticity. We examined whether LIM-HD genes and their co-factors are regulated during kainic acid induced seizure in the adult rat hippocampus as well as in early postnatal rats, when the hippocampal circuitry is not fully developed. We report a distinct and field-specific regulation of LIM-HD genes $L h x 1, L h x 2$, and $L h x 9$, LIMonly gene Lmo4, and cofactor Clim $1 a$ in the adult hippocampus after seizure induction. In contrast none of these genes displayed altered levels upon induction of seizure in postnatal animals. Our results provide evidence of temporal and spatial seizure mediated regulation of LIM-HD family members and suggest that LIM-HD gene function may be involved in activity dependent plasticity in the adult hippocampus

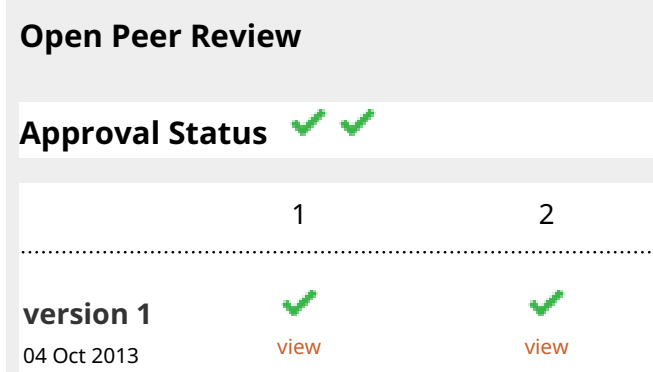

1. Bin Chen, University of California Santa Cruz, Santa Cruz, CA, USA

Matthew Eckler, University of California at Santa Cruz,

\section{Stan Leung, University of Western Ontario, London, ON, Canada}

Any reports and responses or comments on the article can be found at the end of the article. 
Corresponding authors: Vidita A. Vaidya (vvaidya@tifr.res.in), Shubha Tole (shubhatole@gmail.com)

Competing interests: No competing interests were disclosed.

Grant information: This work was supported by a Wellcome trust Senior Fellowship (056684/Z/99/Z), a Swarnajayanti Fellowship (Dept. of Science and Technology, Govt. of India) and a Lady Tata Memorial Trust to ST; a Wellcome Trust International Senior Research Fellowship (04082003114133) to VV, and a Kanwal Rekhi Career Development Award (Tata Institute of Fundamental Research Endowment Fund) to LS.

The funders had no role in study design, data collection and analysis, decision to publish, or preparation of the manuscript.

Copyright: ( 2013 Lakhina V et al. This is an open access article distributed under the terms of the Creative Commons Attribution License, which permits unrestricted use, distribution, and reproduction in any medium, provided the original work is properly cited. Data associated with the article are available under the terms of the Creative Commons Zero "No rights reserved" data waiver (CC0 1.0 Public domain dedication).

How to cite this article: Lakhina V, Subramanian L, Huilgol D et al. Seizure evoked regulation of LIM-HD genes and co-factors in the postnatal and adult hippocampus [version 1; peer review: $\mathbf{2}$ approved] F1000Research 2013, 2:205

https://doi.org/10.12688/f1000research.2-205.v1

First published: 04 Oct 2013, 2:205 https://doi.org/10.12688/f1000research.2-205.v1 


\section{Introduction}

Transcription factors regulate gene expression in the mammalian brain, playing a critical role in both neurodevelopment and in neuronal plasticity during its lifespan. During development, transcription factor mediated regulation is essential for appropriate cell fate specification, cell migration and connectivity ${ }^{1-3}$. Transcription factors also regulate plasticity including activity-dependent process of dendritic pruning, axonal sprouting and cell proliferation and survival $^{4-6}$

One family of transcription factors, the LIM-homeodomain (LIM-HD) family, is known to play critical roles in regulating cell proliferation, axon outgrowth and pathfinding across several systems $^{7-11}$. The LIM-HD proteins have a C-terminal homeodomain which binds to DNA and two zinc finger "LIM" domains that bind co-factors encoded by the Clim genes. The transcriptionally active complex is a tetramer comprising two LIM-HD molecules bridged by a dimer of two Clim molecules ${ }^{12,13}$. LIM-only (Lmo) proteins lack the homeodomain but can bind Clim molecules, and function as dominant-negative regulators of LIM-HD function ${ }^{12,14,15}$. At least thirteen LIM-HD (Lhx) genes four Lmo genes and two Clim genes have been identified in the mouse. A subset of genes is expressed in the embryonic and mature hippocampus and of these, $\operatorname{Lh} \times 2$ and $L h x 5$ are critical to hippocampal development ${ }^{16}$. Lhx 2 plays a fundamental role in early telencephalic development as a cortical selector gene ${ }^{11}$. The neocortex and hippocampus do not form in the absence of $L h x 2^{11,17}$. At later stages, $L h x 2$ plays a new role in the developing hippocampus, as a necessary and sufficient repressor of astrogliogenesis ${ }^{18}$. Lhx 2 continues to be expressed in the mature hippocampus. Lhx5 is critical for hippocampal development at early stages, but is not expressed in the embryonic hippocampus once it is specified ${ }^{19}$. Lhx1, Lhx9, Climla, Clim2, Lmo3 and Lmo4 are all expressed in the hippocampus at embryonic and adult stages $^{16}$, but no loss of function phenotypes have been reported in the hippocampus.

While several studies have implicated the LIM-HD family as a key modulator of important neurodevelopmental events, the understanding of the role of this transcription factor family in the postnatal and adult brain remains relatively unexplored. These transcription factors are known to regulate cell proliferation ${ }^{8,20}$, axon pathfinding ${ }^{21,22}$ and neurite outgrowth ${ }^{23,24}$. These phenomena have parallels in the structural plasticity that occurs in postnatal and adult life. It is now well established that the same molecules that bring about the early development of the hippocampus are often reutilized in adult reorganization and structural plasticity ${ }^{25-27}$. Several LIM-HD family members continue to be expressed in the adult hippocampus ${ }^{16}$ (this study). Therefore, we explored whether these genes display activity-dependent regulation in the adult hippocampus, to provide a basis for studies that may uncover new functions for these genes in maturity.

Activity dependent neuronal plasticity has been suggested to reutilize key developmental pathways to evoke plasticity in the mature nervous system. In particular, seizure models have been shown to induce dramatic changes in progenitor proliferation, axonal sprouting, dendritic reorganization, changes in neuronal cell survival and progenitor differentiation within the hippocampus ${ }^{28-31}$.
Intriguingly, the nature of neuroplastic changes evoked by seizures differs quite dramatically in the postnatal versus the adult brain $^{32-34}$. Regulation at the level of signaling and transcription factors has been shown to be important for structural plasticity in the hippocampus ${ }^{35}$. While neuronal activity and seizures are likely to recruit major developmental signalling pathways in the hippocampus, thus far the role of key developmental transcription factor families as targets is relatively unexplored.

An earlier study reported that LIM-only genes Lmol, 2 and 3 are differentially regulated in a field-specific manner in the adult rat hippocampus in response to kainic acid-induced seizure ${ }^{36}$. We examined a broader set of Lmo and LIM-HD genes as well as their co-factors in a similar paradigm, not only in the adult rat hippocampus, but also in early postnatal stages when hippocampal circuitry is not fully developed ${ }^{37-39}$. Our study provides evidence that LIM-HD, LIM-only, and Clim gene mRNA displays selective field-specific regulation in the hippocampus in response to kainate induced seizures. This provides a basis to explore potential new functions of these genes in activity-dependent synaptic plasticity.

\section{Results}

In this study we focused on LIM-HD genes that are expressed in the adult hippocampus, $L h x 1, L h x 2$ and $L h x 9$ and their co-factors, Climla and Clim2. Among the LIM-only genes, Lmo1, Lmo2, and Lmo3 have been previously reported to display differential regulation in kainate-induced seizure ${ }^{36}$. In our study, we included Lmo3 as a control to allow comparison with the earlier study ${ }^{36}$, and also Lmo4 which was not examined previously. We examined the mRNA expression of these genes at postnatal day P7 when the hippocampal circuitry is not yet fully developed, and also in adult rats (2-3 months old) with mature hippocampal neurocircuitry.

\section{Differential expression of LIM family members and their co-factors across different hippocampal fields}

We used non-radioactive in-situ hybridization to examine gene expression in the CA1 and CA3 fields of the Ammon's horn as well as the dentate gyrus (DG) of control animals (Figure 1a). Lhxl transcripts were not detectable in the hippocampus at P7, and only weakly expressed in the adult DG (Figure 1b). In contrast, Lhx2 and $\operatorname{Lh} x 9$ are expressed intensely in the DG and CA3, with weaker expression in CA1 at P7. In the adult, expression was strong in the DG, but weak in CA1 and CA3 (Figure 1c, d). Lmo3 and Clim2 are strongly expressed in CA1 and DG, with weaker expression in the $\mathrm{CA} 3$ region at both stages (Figure 1e, h). Lmo4 shows strong expression in CA1 but is weakly expressed in CA3 and DG at both stages (Figure 1f). Climla displays expression in all fields at P7, but is weak to undetectable in CA3 in the adult (Figure 1g).

Activity is known to regulate structural plasticity and neurogenesis in the adult hippocampus ${ }^{40,41}$. We administered kainate intraperitoneally to both early postnatal and adult rats to induce seizures as a model of activity and analysed whether there is differential regulation of LIM genes in response to kainate-evoked seizures 6 hours later. All animals administered kainate exhibited classical hallmarks of seizure. Using radioactive in-situ hybridization and optical densitometry we assessed the expression of $\operatorname{Lhx} 1, \operatorname{Lh} x 2, \operatorname{Lh} x$ 9, Lmo3, Lmo4, Clim1a and Clim2 in the postnatal and adult hippocampal 

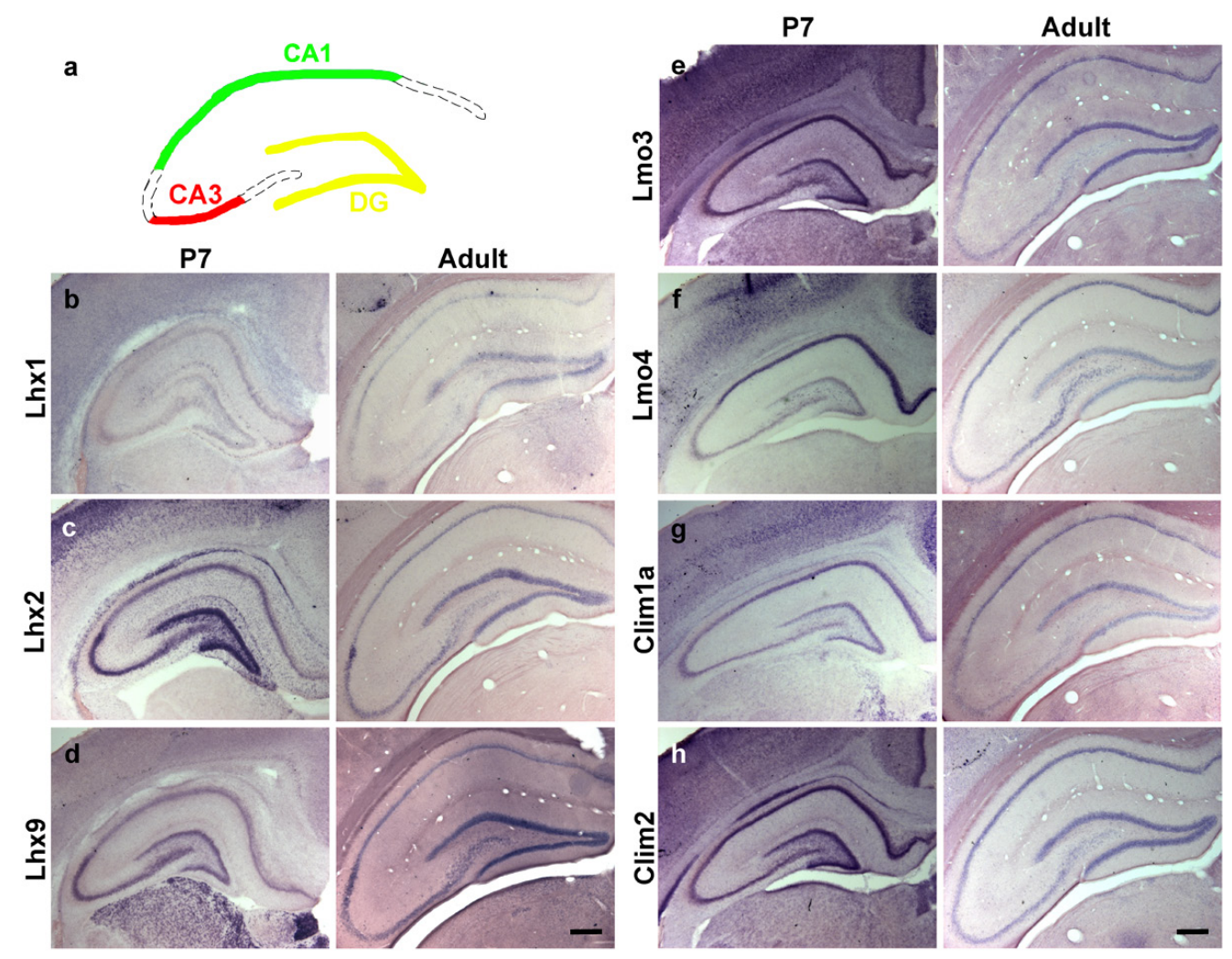

Figure 1. Expression of LIM genes and co-factors in early postnatal and adult hippocampus. (a) A schematic illustrating hippocampal subfields; dentate gyrus (DG) (yellow), CA3 (red) and CA1 (green) fields of Ammon's horns. (b-d) Non-radioactive in-situ hybridization of LIM-homeodomain genes at postnatal day (P)7 and in adult control animals showing differential expression of LIM-homeodomain genes; Lhx1 (b), Lhx2 (c) and Lhx9 (d), Lmo3 (e), Lmo4 (f) Clim1a (g), Clim2 (h) across the hippocampal subfields. Scale bars $=200 \mu m$.

subfields (see Materials and methods). Radioactive in-situ hybridization has an important advantage over quantitative PCR since it provides spatial resolution. The hippocampal CA1 and CA3 fields are molecularly distinct, and the dentate gyrus contains a distinct cell population from the Ammon's horn ${ }^{42}$. Therefore it is necessary to quantitate the gene expression in each region individually.

Seizure induced regulation of LIM family members and their co-factors in the adult dentate gyrus (DG)

The DG displays robust structural changes in response to seizure. Increase in dentate granule cell neurogenesis ${ }^{43}$ and extensive mossy fiber sprouting ${ }^{41,44}$ are hallmarks of kainate induced seizure. Upon kainate treatment, the expression of Lhxl showed a striking increase $(25 \% ; \mathrm{p}=0.019)$ in the adult DG. This is in contrast with the adult $L h x 2$ and $L h x 9$ expression, the mRNA levels of which show a drastic reduction $(60 \%$ for $\operatorname{Lh} x 2, \mathrm{p}=0.0004$ and $36 \%$ for $\operatorname{Lh} x 9$, $\mathrm{p}=0.003$; Figure 2, Figure 3a). Interestingly, the LIM-only genes Lmo3 and Lmo4 also showed opposite changes: whereas Lmo3 levels decreased significantly $(53 \%, \mathrm{p}=0.002)$, Lmo 4 mRNA levels showed a remarkable increase $(55 \%, \mathrm{p}=0.009)$ in kainate-treated animals. The decrease in $L m o 3$ levels was consistent with that reported previously ${ }^{36}$. The mRNA levels of the cofactor Climla decreased slightly in treated animals $(15 \%, \mathrm{p}=0.048)$ whereas no significant difference was observed with Clim2 (Figure 2, Figure 3b).

Seizure induced regulation of LIM family members and their co-factors in the adult CA3 subfield

The CA3 subfield has pyramidal neurons, which receive input from the dentate granule cells. They display profound alterations in dendritic structure and branching in response to seizure. In our experiments using kainate-induced seizure, $L h x 1 \mathrm{mRNA}$ increased (20\%, p $=0.014)$ in the adult CA3. In contrast, Lhx2 and Lhx9 levels decreased $(30 \%, \mathrm{p}=0.028 ; 35 \%, \mathrm{p}=0.044$ respectively; Figure 2, Figure 4a). Levels of both $\mathrm{Lmo}_{3}$ and $\mathrm{Lmo} 4$ were reduced $(40 \%, p=0.007 ; 25 \%, p=0.002$ respectively). The levels of the cofactor Climla also decreased $(15 \%, \mathrm{p}=0.047)$ whereas Clim 2 levels remained unaltered in the adult CA3 (Figure 2, Figure 4b).

Seizure induced regulation of LIM family members and their co-factors in the adult CA1 subfield

The CA1 pyramidal neurons receive input from the CA 3 neurons. They displayed altered dendritic shape and density and also axon sprouting as a result of seizure ${ }^{45}$. In the CA1 field, $L h x 1$ mRNA increased (20\%, p = 0.02), whereas Lhx2 levels decreased $(19 \%, \mathrm{p}=0.024)$ but, 


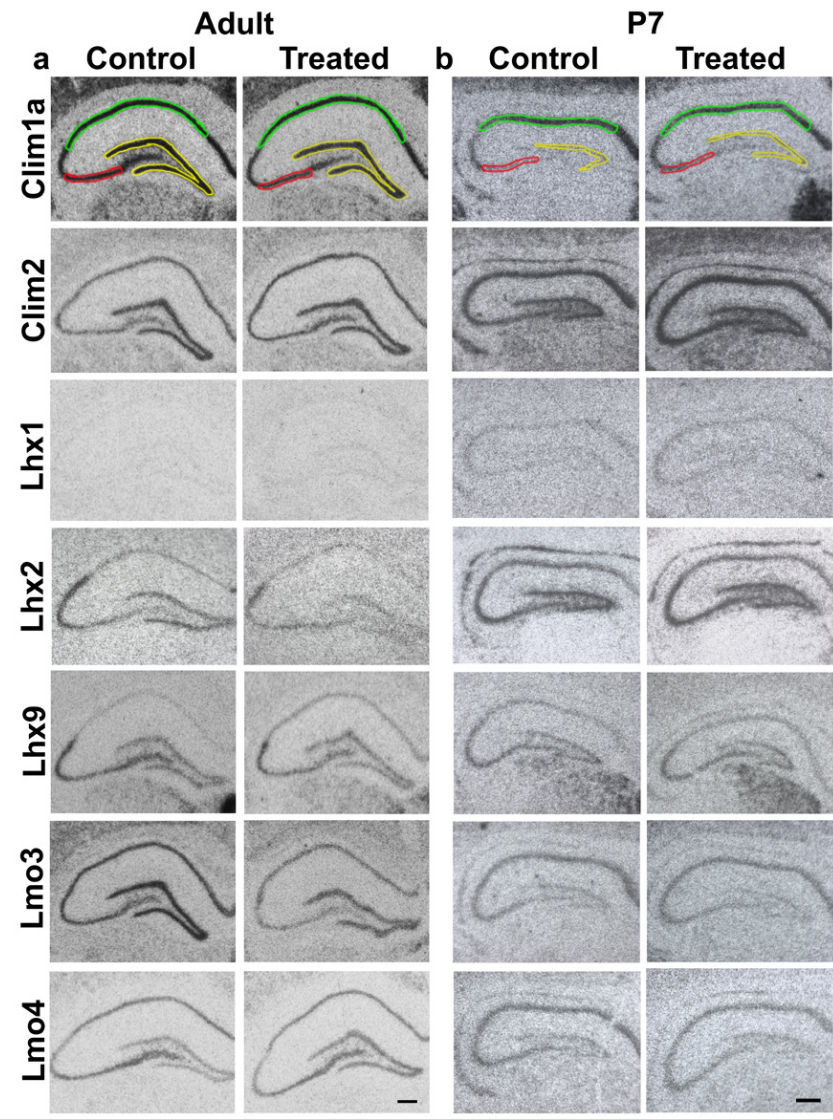

Figure 2. Expression of LIM genes and co-factors used for densitometric analysis. Representative images of sections of brains from control and kainate-administered animals processed for radioactive in-situ hybridization of LIM-homeodomain genes in the hippocampus. 1 section from each condition is shown for adult (a) and P7 (b) animals. Colored lines mark the areas for quantification of expression in different hippocampal subfields: DG (yellow); CA3 (red); CA1 (green). Scale bars $=200 \mu \mathrm{m}$.

there was no change in $\operatorname{Lh} x 9$ mRNA levels in the adult CA1 upon kainate-induced seizure (Figure 2, Figure 5a). Lmo3 mRNA levels decreased $(41 \%, \mathrm{p}=0.0018)$ whereas Lmo4, Climla, and Clim2 levels remained unchanged (Figure 2, Figure $5 b$ ).

\section{A summary of seizure induced regulation of LIM family} members and their co-factors across all hippocampal fields Table 1 summarizes the data such that seizure-induced regulation can be compared within a particular field as well as for a particular gene across all fields. For example, upon kainate induced seizure, Lhxl mRNA shows a significant increase over very low baseline expression in all the hippocampal fields in response to seizure. In contrast, Lhx2 and Lmo3 show a significant decrease in all hippocampal fields. Interestingly, Lhx 9 and Climla show a significant decrease in CA3 and DG, but not in CA1. Lmo4 transcript levels increase in the DG, decrease in the CA3 and show no change in the CA1. This correlates with the fact that the DG and CA3 undergo a more drastic structural reorganization in response to seizure ${ }^{46,47}$. Clim 2 shows no alteration suggesting it may not have any additional roles in kainate-induced plasticity, but continues to be available to LIM-HD transcription factors at the same levels.

\section{Seizures do not affect LIM-gene expression in the postnatal hippocampus}

Seizure evoked structural plasticity differs between the postnatal and adult hippocampus in its extent as well as the type of changes seen. Although postnatal kainate treatment evokes powerful seizures, the immature brain is relatively resistant to seizure-evoked structural remodeling. For example, mossy fiber sprouting is absent or delayed ${ }^{48-50}$, and DG neurogenesis is unaltered or biphasically regulated with an initial decline and a delayed increase ${ }^{51-53}$ in response to seizure in the postnatal hippocampus. We asked whether the postnatal hippocampus differs from the adult hippocampus in kainic acid induced regulation of LIM genes and co-factors. We administered kainic acid to rat pups on postnatal day P7 and analyzed changes in transcript levels of several LIM genes 6 hours later. In striking contrast to the changes observed in the adult brain, the postnatal hippocampus appears refractory to regulation of the LIM-HD family following kainate evoked seizures (Figure 2, Figure 3c, d, Figure 4c, d, Figure 5c, d).

In summary, the LIM gene family and its co-factors display distinct and highly field-specific regulation in response to kainate induced seizure in the adult, but not in the postnatal hippocampus.

\section{Seizure evoked regulation of LIM genes in the hippocampus}

1 Data Widget

http://dx.doi.org/10.6084/m9.figshare. 807690

\section{Discussion}

Differential regulation of LIM-gene expression in response to seizures

Seizures can lead to different forms of hippocampal plasticity, which include axonal/dendritic remodeling and neurogenesis. Chemicalinduced seizures like the kainic acid (kainate) treatment are used as

Table 1. Summary of seizure evoked regulation of LIM genes and co-factors across the hippocampal fields.

\begin{tabular}{|c|c|c|c|c|c|c|}
\hline \multirow{2}{*}{ LIM gene } & \multicolumn{2}{|c|}{ DG } & \multicolumn{2}{|c|}{ CA3 } & \multicolumn{2}{|c|}{ CA1 } \\
\hline & Adult & P7 & Adult & P7 & Adult & P7 \\
\hline Lhx1 & $\uparrow$ & _- & $\uparrow$ & _- & $\uparrow$ & _- \\
\hline Lhx2 & $\downarrow$ & - & $\downarrow$ & - & $\downarrow$ & - \\
\hline Lhx9 & $\downarrow$ & - & $\downarrow$ & - & - & - \\
\hline Lmo3 & $\downarrow$ & - & $\downarrow$ & - & $\downarrow$ & - \\
\hline Lmo4 & $\uparrow$ & - & $\downarrow$ & - & - & - \\
\hline Clim1a & $\downarrow$ & - & $\downarrow$ & - & - & - \\
\hline Clim2 & _ & _- & _- & _- & _- & _- \\
\hline
\end{tabular}



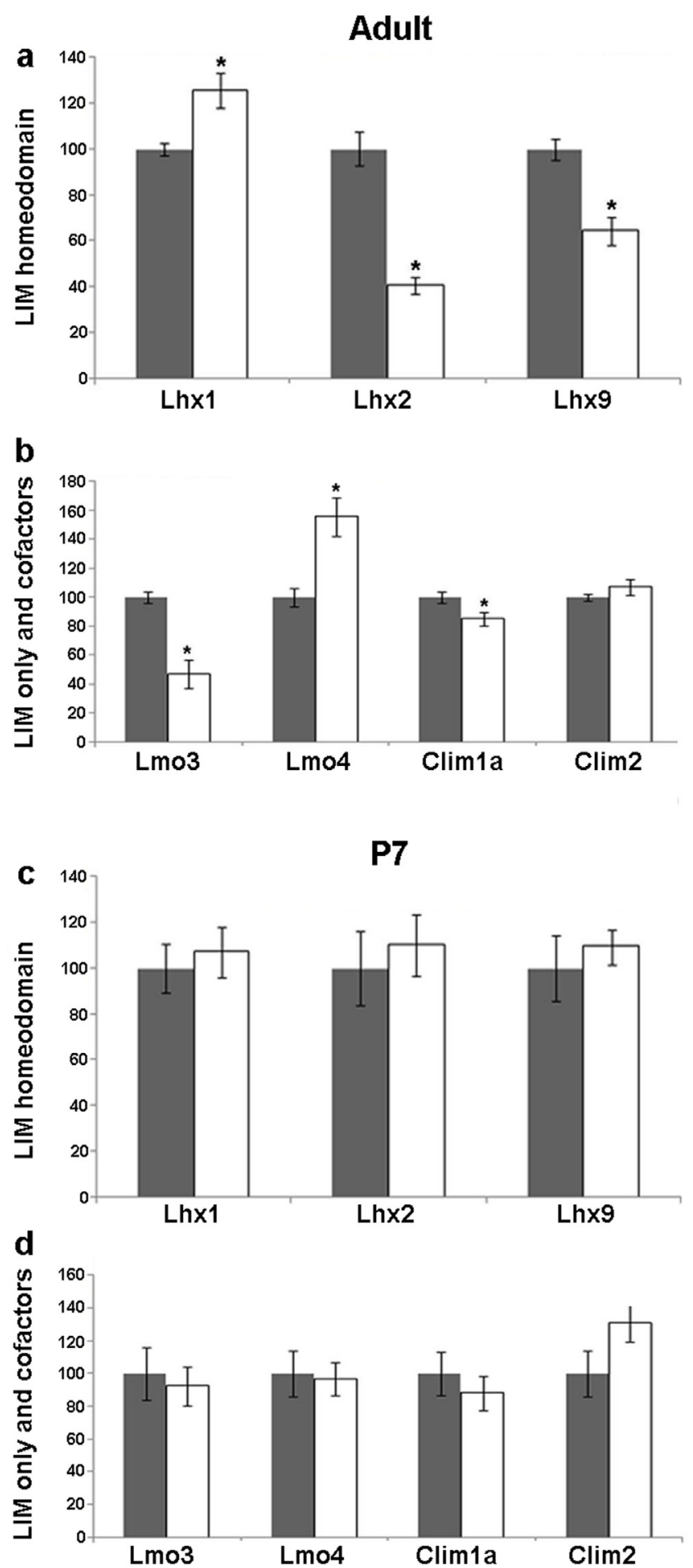

Figure 3. Kainate-induced regulation of LIM genes and cofactors in the dentate gyrus (DG) of adult and P7 rats. Quantitative densitometric analysis of the adult DG region following kainate administration in adult $(\mathbf{a}, \mathbf{b})$ and P7 $(\mathbf{c}, \mathbf{d})$ rats. Grey bars are controls, white bars are kainate treated animals. Results are expressed as mean \pm SEM percentage of control for mRNA expression $\left({ }^{*} p<0.05\right.$, unpaired Student's $t$ test). models for epilepsy and have been shown to increase neurogenesis in the adult $\mathrm{DG}^{28}$ and extensive mossy fiber sprouting where mossy fibers aberrantly synapse onto dentate granule cells instead of CA3 pyramidal neurons $\mathrm{s}^{41,44}$. Kainic acid administration causes animals to display motor signs including convulsions. In our experiments, we observed changes in the transcript levels 6 hours post kainic acid administration, after the animals displayed all the characteristic physical stages of seizures. In future experiments it would be interesting to examine whether any LIM gene transcript regulation occurs in a shorter time window post kainic acid administration, prior to the physical manifestation of seizure by the animal.

Transcription factors important for brain development are also known to regulate structural changes and reorganization in the adult brain, one example being members of the basic Helix-Loop-Helix (bHLH) family ${ }^{25,26}$. Members of the LIM-HD family of transcription factors are necessary for different aspects of the development of the hippocampus ${ }^{11,18,19}$, a structure that is vulnerable to changes in response to activity. LIM genes are differentially expressed in both the postnatal and adult hippocampus, suggesting that there might be a role for these genes in postnatal circuit development and adult reorganization ${ }^{16}$. We therefore hypothesized that the LIM-HD family members are differentially regulated in response to activity. Indeed, from our analysis of radioactive in-situ hybridization, we find that each hippocampal field displays differential expression and post-seizure regulation of different LIM genes. LIM-only genes Lmo1, 2 and 3 were previously shown to be regulated in response to kainate-induced seizures in the adult hippocampus ${ }^{36}$. We report that Lmo4 is also regulated by kainate-induced seizures throughout the hippocampus. We also discovered that LIM-HD genes Lhxl, Lhx2, Lhx 9 and cofactor Climla are differentially regulated in response to seizures in a field-specific manner. Furthermore, we show that this differential regulation of LIM genes is restricted to adult animals and when we administered kainic acid to postnatal pups, no such regulation was observed. This is intriguing because these results highlight that a developing system such as the hippocampal circuitry in the early postnatal brain is relatively resistant to seizure-induced structural remodelling and plasticity ${ }^{32}$. For example, in the adult, seizure induces an increase in DG neurogenesis whereas in early postnatal stages, it is either decreased or unchanged $^{34}$. Our results raise the intriguing possibility that such differences in molecular regulation of transcription factors may underlie the differing nature of cellular changes evoked by seizures in the postnatal versus adult brain.

\section{Structural changes in the hippocampus}

Seizure leads to an increase in neuronal activity thereby inducing the transcription of several immediate early genes (IEGs). The IEGs are hypothesized to be involved in seizure-induced structural remodelling ${ }^{54}$. The LIM family of transcription factors could be part of effector cascades downstream of these IEGs, which may eventually lead to the structural changes seen in different hippocampal subfields. CREB, a well-known activity regulated transcription factor, has been shown to interact in the same transcriptional complex as Lmo4 in response to activity ${ }^{55}$. It is also interesting to note that well known seizure-responsive IEGs in the adult hippocampus, such as the AP- 1 complex, are not regulated by postnatal seizures ${ }^{56}$. This further supports the idea that distinct molecular changes evoked by 
Adult
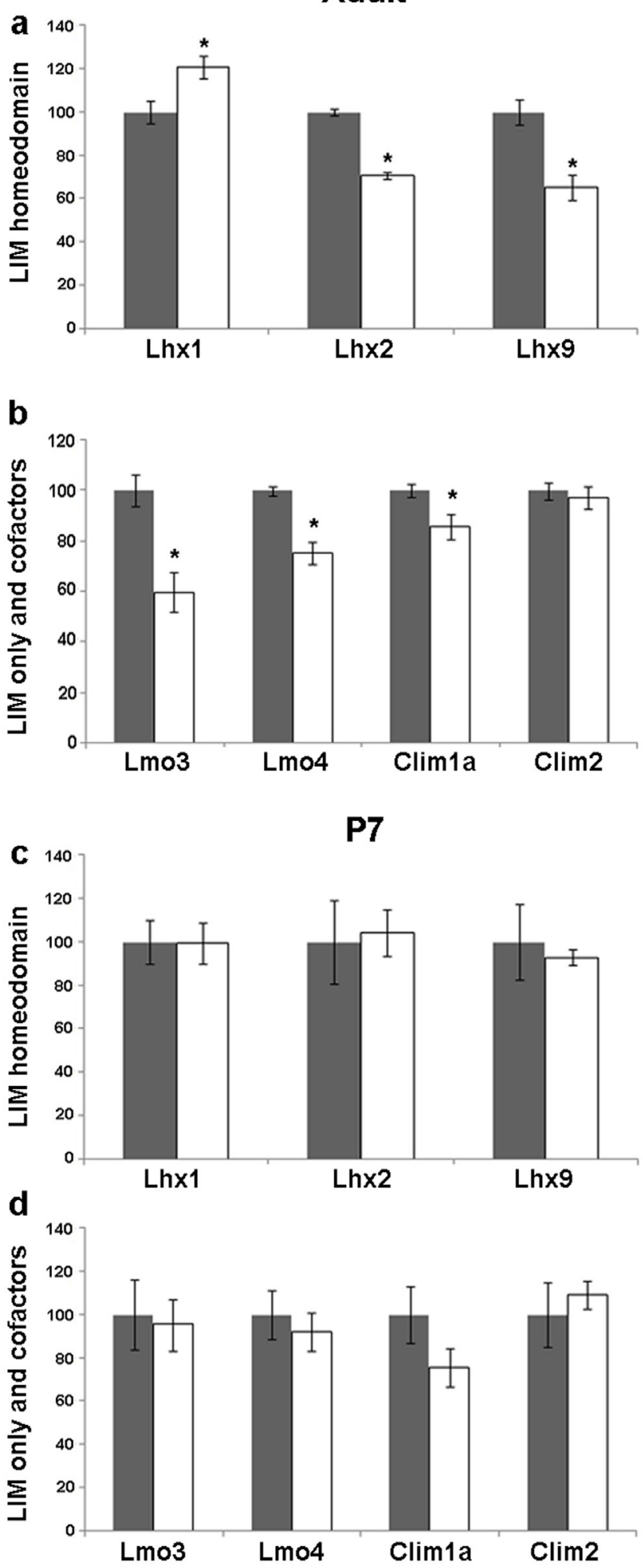

Figure 4. Kainate-induced regulation of LIM genes and co-factors in CA3 of adult and P7 rats. Quantitative densitometric analysis of the adult CA3 region following kainate administration in adult $(\mathbf{a}, \mathbf{b})$ and P7 (c,d) rats. Grey bars are controls, white bars are kainate treated animals. Results are expressed as mean \pm SEM percentage of control for mRNA expression ( ${ }^{*} p<0.05$, unpaired Student's $t$ test) postnatal versus adult seizures may contribute to the age-dependent differences in seizure-evoked plasticity.

Distinct structural changes occur in response to seizure in different subfields of the hippocampus. On seizure induction, DG shows an increase in the granule cell neurogenesis ${ }^{46}$, enhanced integration of granule cells into the neurocircuitry, a profound increase in mossy fiber sprouting by these neurons and formation of recurrent synapses ${ }^{57-59}$. The CA3 and CA1 pyramidal neurons show a loss of dendritic spine and dendritic branches ${ }^{47}$ post seizure. Some axon sprouting is also seen in CA1 neurons ${ }^{45,60}$. LIM genes may bring about activity induced structural changes in the hippocampus. They are known to regulate neurite outgrowth ${ }^{24}$. Some LIM-HD genes also control key axon guidance molecules such as Eph/ephrins ${ }^{61}$, which affect mossy fiber sprouting in the DG ${ }^{62}$. Lhx 1 is known to regulate the transcription of Eph/ephrins in a subset of motor neurons ${ }^{61}$. Our results show increased $L h x 1$ mRNA levels in the DG in response to seizure that could lead to increased Eph/ ephrin levels therefore contributing to mossy fiber sprouting. Lhx2 represses Robo1 and 2 expression in the thalamus during thalamocortical pathfinding 22 and so down regulation of $L h \times 2$ mRNA in response to seizure could be important for mossy fiber sprouting via upregulation of the Robo receptors. Lmo4 has been shown to confer a neuroprotective role in response to hypoxia ${ }^{63}$. Interestingly, we find an increase in the Lmo4 mRNA after kainate treatment, which could lead to neuronal survival in response to seizure.

Our study provides new evidence of seizure mediated regulation of LIM-HD transcription factors. We show that this regulation is age-dependent and field specific. Future experiments will aim at testing whether LIM genes are necessary for mediating seizure induced structural alterations. Examining the effect of kainic acid treatment on structural changes such as DG neurogenesis in LIM gene loss-of-function mutants will begin to address this issue. In addition, determining the interactions of LIM gene family proteins with other factors known to mediate structural changes such as the bHLH family members ${ }^{25,26}$ will open avenues for the mechanistic understanding of this process. These results therefore provide impetus for future studies to explore the role of the LIM-HD transcription factors, LIM only genes, and their cofactors in activity-dependent reorganization and plasticity in the mature nervous system.

\section{Materials and methods}

\section{Animals and treatment paradigm}

Sprague-Dawley rats were bred in the Tata Institute of Fundamental Research (TIFR) Animal house, maintained under normal 12-hour light/dark cycle and were provided with food and water $a d$ libitum. A total of 84 adults and 101 pups (P7) were used. Adults were between 2-3 months old and weighed between 200-250 grams. All animal procedures were performed in accordance with the NIH guidelines for use and maintenance of animals and were approved by the TIFR Institutional Animal Ethics committee. The male rats were sexed at P21 and were used for experiments when they reached adulthood. Postnatal pups of both sexes were used for experiments at P7. All animals were grouped based on their treatment with either saline (control group; $n=44$ adults; $n=47$ P7 pups) or with $10 \mathrm{mg} / \mathrm{kg}$ kainic acid (Sigma, USA; $\mathrm{n}=40$ adults; $\mathrm{n}=54 \mathrm{P} 7$ pups) administered intraperitoneally and were housed 


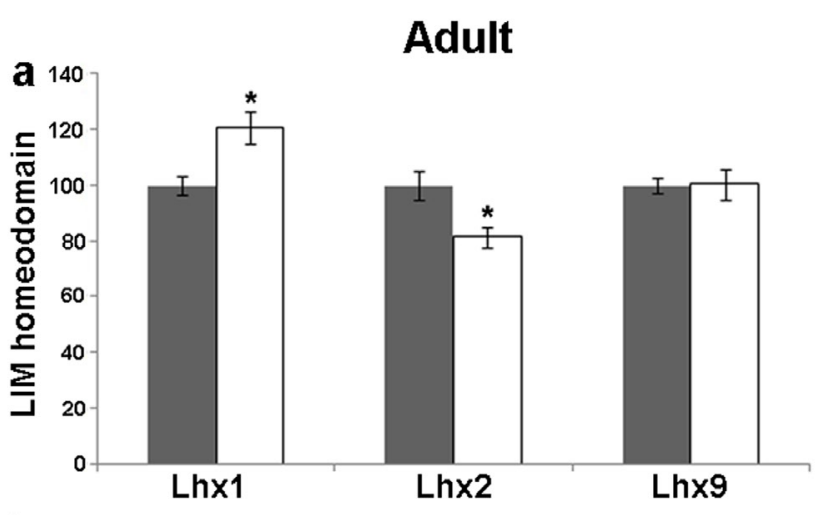

b
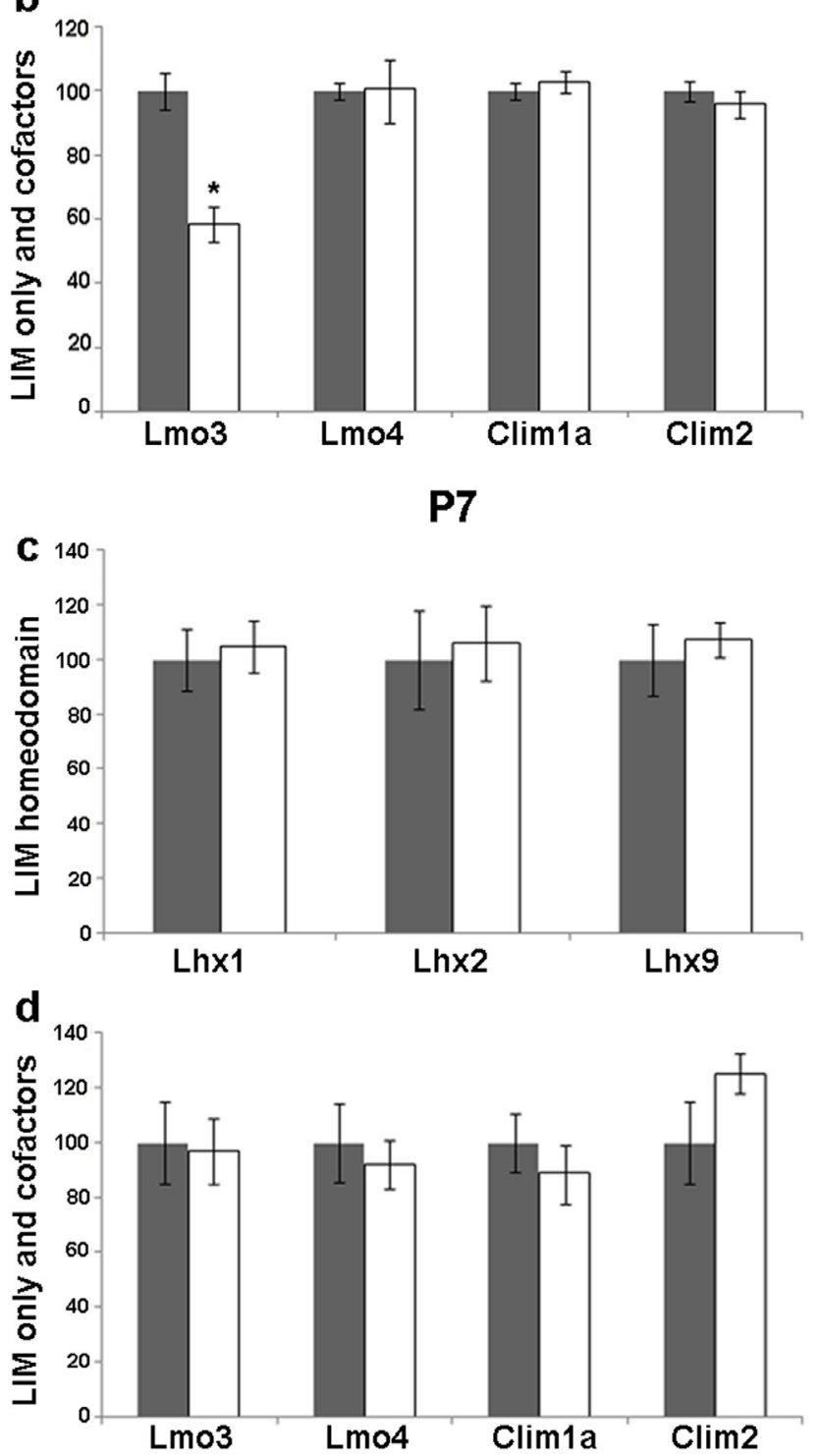

Figure 5. Kainate-induced regulation of LIM genes and co-factors in CA1 of adult and P7 rats. Quantitative densitometric analysis of the adult CA1 region following kainate administration in adult $(\mathbf{a}, \mathbf{b})$ and P7 $(\mathbf{c}, \mathbf{d})$ rats. Grey bars are controls, white bars are kainate treated animals. Results are expressed as mean \pm SEM percentage of control for mRNA expression ( ${ }^{*} p<0.05$, unpaired Student's $t$ test). isolated for 6 hours after the treatment. The kainic acid treated group was observed every 30 minutes across the 6 hours and displayed all the characteristic stages of seizures. The animals displayed facial clonus (Racine Stage 1) to front and hindlimb clonus and continuous falling down (Racine Stage 5).

Animals were decapitated using a guillotine 6 hours after treatment and the brains were immediately frozen on dry ice and stored at $-70^{\circ} \mathrm{C}$. Coronal sections $(14 \mu \mathrm{m})$ were generated on the cryostat and mounted onto Probe-plus RNase free slides (Electron Microscopy Sciences, USA). Slides were then treated with 4\% paraformaldehyde (PFA; Merck Chemicals), washed in 1X phosphate-buffered saline, acetylated with acetic acid (Qualigens Fine Chemicals) in $0.1 \mathrm{M}$ triethanolamine (Sigma-Aldrich), rinsed in $2 \mathrm{X}$ sodium saline citrate (SSC), $\mathrm{pH} 4.5$ and then dehydrated through grades $(30 \%, 70 \%$ and $100 \%$ in double distilled water) of ethanol (Commercial Alcohols, Ontario, Canada) prior to storage at $-70^{\circ} \mathrm{C}$.

\section{mRNA in-situ hybridization}

The in-situ hybridization for DIG-labeled probes was carried out as described previously (Bulchand et al., 2003) ${ }^{16}$. Plasmid DNAs encoding different LIM genes and co-factors were linearized by restriction digestion to provide template for making DIG-labeled RNA probe ${ }^{16}$. Briefly, the slides were incubated in hybridization buffer (50\% formamide, $5 \mathrm{X}$ SSC and $1 \%$ SDS) containing DIG-labeled riboprobes (Roche) for 16 hours at $70^{\circ} \mathrm{C}$ followed by post-hybridization washes using Solution X (50\% formamide, $2 \mathrm{X}$ SSC and $1 \%$ SDS), $2 X$ SSC and 0.2X SSC.

Radioactive in-situ hybridization was carried out as described previously ${ }^{64}$. Briefly, the slides were incubated in the hybridization buffer $(50 \%$ formamide, $0.6 \mathrm{M}$ sodium chloride, $10 \mathrm{mM}$ Tris $\mathrm{pH}$

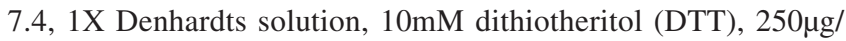
$\mathrm{ml}$ yeast tRNA, $50 \mu \mathrm{g} / \mathrm{ml}$ Salmon sperm DNA, $10 \%$ Dextran sulphate) containing ${ }^{35} \mathrm{~S}$-UTP labeled riboprobes (Amersham, Buckinghamshire, UK) at a concentration of $10^{6} \mathrm{cpm} / 250 \mu \mathrm{l}$ for $20-24$ hours at $60^{\circ} \mathrm{C}$. Post-hybridization, the slides were washed with 2XSSC, treated with RNase A $\left(20 \mu \mathrm{g} / \mathrm{ml}\right.$ for 30 minutes at $37^{\circ} \mathrm{C}$; USB Corporation, Cleveland, Ohio), $0.5 \mathrm{X}$ SSC for 30 minutes at $60^{\circ} \mathrm{C}, 0.1 \mathrm{X}$ SSC for 20 minutes and then rinsed in double distilled water. Slides were air dried and exposed to Biomax film (Kodak) for 3-6 weeks. To confirm the specificity of the signal observed with antisense riboprobes, controls used were sense riboprobes or RNase treatment $\left(40 \mu \mathrm{g} / \mathrm{ml}\right.$ at $37^{\circ} \mathrm{C}$ for 30 minutes) prior to hybridization.

\section{Quantitation and data analysis}

Densitometric analysis of LIM gene transcript levels was performed using the Macintosh-based Scion Imaging software (Scion, Frederick, Maryland, USA). Sections were observed directly on the monitor using a Sony 3 CCD color video camera (Model DXC-390P). ${ }^{14} \mathrm{C}$ standards were used for calibration to correct for non-linearity. An equivalent area was outlined for each of the hippocampal subfields and optical density measurements from both hemispheres of 3-4 individual sections from each animal were analysed to calculate the mean value. Results were subjected to statistical Student's t-test. Significance was determined at $\mathrm{p}<0.05$ using GraphPad 
inSTAT (version 3.05, LaJolla, California, USA). The following numbers of animals were used for each condition: Control adults, $\mathrm{n}=7$ (Clim1a), 9 (Clim2), 5 (Lhx1), 5 (Lhx2), 5 (Lhx9), 4 (Lmo3), 9 (Lmo4). Kainate treated adults, $\mathrm{n}=8$ (Clim1a), 8 (Clim2), 5 (Lhx1), 4 (Lhx2), 4 (Lhx9), 3 (Lmo3), 8 (Lmo4). Control pups, $\mathrm{n}=6$ (Clim1a), 8 (Clim2), 6 (Lhx1), 8 (Lhx2), 5 (Lhx9), 7 (Lmo3), 7 (Lmo4). Kainate treated pups, $\mathrm{n}=8$ (Clim1a), 8 (Clim2), 8 (Lhx1), 8 (Lhx2), 7 (Lhx9), 8 (Lmo3), 7 (Lmo4).

\section{Author contributions}

VL, LS, VV, ST conceived the project. VL, LS, DH, AS performed the experiments, analyzed the data, and helped to critically revise the paper. DH, VV, ST analyzed the data and wrote the paper.

\section{Competing interests}

No competing interests were disclosed.

\section{Grant information}

This work was supported by a Wellcome trust Senior Fellowship (056684/Z/99/Z), a Swarnajayanti Fellowship (Dept. of Science and Technology, Govt. of India) and a Lady Tata Memorial Trust to ST; a Wellcome Trust International Senior Research Fellowship (04082003114133) to VV, and a Kanwal Rekhi Career Development Award (Tata Institute of Fundamental Research Endowment Fund) to LS.

The funders had no role in study design, data collection and analysis, decision to publish, or preparation of the manuscript.

\section{Acknowledgements}

We thank B. Anderson, F. Porter, Y. Nakagawa, I. Bach and E. A. Grove for gifts of plasmid DNA to make cRNA probes for in situ hybridization; SB Banerjee for assistance with the radioactive in-situ hybridization experiments. We thank Dr. Yashwantrao Mane and the TIFR Animal House staff for excellent support.
1. Guillemot F: Cell fate specification in the mammalian telencephalon.

Prog Neurobiol. 2007; 83(1): 37-52.

PubMed Abstract | Publisher Full Text

2. Polleux F, Ince-Dunn G, Ghosh A: Transcriptional regulation of vertebrate axon guidance and synapse formation. Nat Rev Neurosci. 2007; 8(5): 331-40. PubMed Abstract | Publisher Full Text

3. Nóbrega-Pereira S, Marín O: Transcriptional control of neuronal migration in the developing mouse brain. Cereb Cortex. 2009; 19(Suppl 1): i107-13. PubMed Abstract | Publisher Full Text

4. Lonze BE, Ginty DD: Function and regulation of CREB family transcription factors in the nervous system. Neuron. 2002; 35(4): 605-23. PubMed Abstract | Publisher Full Text

5. Parrish JZ, Emoto K, Kim MD, et al:: Mechanisms that regulate establishment, maintenance, and remodeling of dendritic fields. Annu Rev Neurosci. 2007; 30: 399-423.

PubMed Abstract | Publisher Full Text

6. West $A E$, Greenberg ME: Neuronal activity-regulated gene transcription in synapse development and cognitive function. Cold Spring Harb Perspect Biol. 2011; 3(6): a005744.

PubMed Abstract | Publisher Full Text | Free Full Text

7. Lundgren SE, Callahan CA, Thor S, et al:: Control of neuronal pathway selection by the Drosophila LIM homeodomain gene apterous. Development. 1995; 121(6): 1769-73.

PubMed Abstract

8. Porter FD, Drago J, Xu Y, et al: Lhx2, a LIM homeobox gene, is required for eye forebrain, and definitive erythrocyte development. Development. 1997; 124(15): 2935-4.

PubMed Abstract

9. Thor S, Andersson SG, Tomlinson A, et al: A LIM-homeodomain combinatorial code for motor-neuron pathway selection. Nature. 1999; 397(6714): 76-80. PubMed Abstract | Publisher Full Text

10. Ando $\mathrm{H}$, Kobayashi M, Tsubokawa $\mathrm{T}$, et al:: Lhx2 mediates the activity of Six3 in zebrafish forebrain growth. Dev Biol. 2005; 287(2): 456-468. PubMed Abstract | Publisher Full Text

11. Mangale VS, Hirokawa KE, Satyaki PR, et al.: Lhx2 selector activity specifies cortical identity and suppresses hippocampal organizer fate. Science. 2008; 319(5861): 304-309.

PubMed Abstract | Publisher Full Text | Free Full Text

12. Milan M, Cohen SM: Regulation of LIM homeodomain activity in vivo: a tetramer of dLDB and apterous confers activity and capacity for regulation by dLMO. Mol Cell. 1999; 4(2): 267-273. PubMed Abstract | Publisher Full Text

13. Thaler JP, Lee SK, Jurata LW, et al:: LIM factor Lhx3 contributes to the specification of motor neuron and interneuron identity through cell-type- specific protein-protein interactions. Cell. 2002; 110(2): 237-249. PubMed Abstract | Publisher Full Text

14. Milan M, Diaz-Benjumea FJ, Cohen SM: Beadex encodes an LMO protein that regulates Apterous LIM-homeodomain activity in Drosophila wing development: a model for LMO oncogene function. Genes Dev. 1998; 12(18): 2912-2920.

PubMed Abstract | Publisher Full Text | Free Full Text

15. Weihe U, Milan M, Cohen SM: Regulation of Apterous activity in Drosophila wing development. Development. 2001; 128(22): 4615-4622. PubMed Abstract

16. Bulchand S, Subramanian L, Tole S: Dynamic spatiotemporal expression of LIM genes and cofactors in the embryonic and postnatal cerebral cortex. Dev Dyn. 2003; 226(3): 460-469.

PubMed Abstract | Publisher Full Text

17. Bulchand S, Grove EA, Porter FD, et al.: LIM-homeodomain gene Lhx2 regulates the formation of the cortical hem. Mech Dev. 2001; 100(2): 165-175. PubMed Abstract | Publisher Full Text

18. Subramanian L, Sarkar A, Shetty AS, et al:: Transcription factor Lhx2 is necessary and sufficient to suppress astrogliogenesis and promote neurogenesis in the developing hippocampus. Proc Natl Acad Sci U S A. 2011 108(27): E265-74.

PubMed Abstract | Publisher Full Text | Free Full Text

19. Zhao $\mathrm{Y}$, Sheng HZ, Amini R, et al:: Control of hippocampal morphogenesis and neuronal differentiation by the LIM homeobox gene Lhx5. Science. 1999; 284(5417): 1155-8.

PubMed Abstract | Publisher Full Text

20. Yan $\mathrm{CH}$, Levesque $\mathrm{M}$, Claxton $\mathrm{S}$, et al:: Lmx1a and Imx1b function cooperatively to regulate proliferation, specification, and differentiation of midbrain dopaminergic progenitors. J Neurosci. 2011; 31(35): 12413-25. PubMed Abstract | Publisher Full Text

21. Lakhina V, Falnikar A, Bhatnagar L, et al.: Early thalamocortical tract guidance and topographic sorting of thalamic projections requires LIM-homeodomain gene Lhx2. Dev Biol. 2007; 306(2): 703-13. PubMed Abstract | Publisher Full Text

22. Marcos-Mondéjar P, Peregrín S, Li JY, et al.: The Ihx2 transcription factor controls thalamocortical axonal guidance by specific regulation of robo1 and robo2 receptors. J Neurosci. 2012; 32(13): 4372-85. PubMed Abstract | Publisher Full Text

23. Hobert O, Tessmar K, Ruvkun G: The Caenorhabditis elegans lim-6 LIM homeobox gene regulates neurite outgrowth and function of particula GABAergic neurons. Development. 1999; 126(7): 1547-1562. PubMed Abstract

24. Manetopoulos C, Hansson A, Karlsson J, et al:: The LIM-only protein LMO4 modulates the transcriptional activity of HEN1. Biochem Biophys Res Commun. 
2003; 307(4): 891-9.

PubMed Abstract | Publisher Full Text

25. Elliott RC, Khademi S, Pleasure SJ, et al: Differential regulation of basic helix-loop-helix mRNAs in the dentate gyrus following status epilepticus. Neuroscience. 2001; 106(1): 79-88.

PubMed Abstract | Publisher Full Text

26. Elliott RC, Miles MF, Lowenstein DH: Overlapping microarray profiles of dentate gyrus gene expression during development- and epilepsy-associated neurogenesis and axon outgrowth. J Neurosci. 2003; 23(6): 2218-27. PubMed Abstract

27. Takasu MA, Dalva MB, Zigmond RE, et al:: Modulation of NMDA receptordependent calcium influx and gene expression through EphB receptors. Science. 2002; 295(5554): 491-5.

PubMed Abstract | Publisher Full Text

28. Parent JM, Lowenstein DH: Seizure-induced neurogenesis: are more new neurons good for an adult brain? Prog Brain Res. 2002; 135: 121-131. PubMed Abstract | Publisher Full Text

29. Nadler JV: The recurrent mossy fiber pathway of the epileptic brain. Neurochem Res. 2003; 28(11): 1649-58.

PubMed Abstract | Publisher Full Text

30. Overstreet-Wadiche LS, Bromberg DA, Bensen AL, et al:: Seizures accelerate functional integration of adult-generated granule cells. J Neurosci. 2006; 26(15): 4095-103.

PubMed Abstract | Publisher Full Text

31. Scharfman HE, McCloskey DP: Postnatal neurogenesis as a therapeutic target in temporal lobe epilepsy. Epilepsy Res. 2009; 85(2-3): 150-61.

PubMed Abstract | Publisher Full Text | Free Full Text

32. Sperber EF, Haas KZ, Stanton PK, et al.: Resistance of the immature hippocampus to seizure-induced synaptic reorganization. Brain Res Dev Brain Res. 1991; 60(1): 88-93.

PubMed Abstract | Publisher Full Text

33. Lynch M, Sayin U, Bownds J, et al:: Long-term consequences of early postnatal seizures on hippocampal learning and plasticity. Eur J Neurosci. 2000; 12(7): 2252-64.

PubMed Abstract | Publisher Full Text

34. Porter BE: Neurogenesis and epilepsy in the developing brain. Epilepsia. 2008 49(Suppl 5): 50-4.

PubMed Abstract | Publisher Full Text | Free Full Text

35. Alberini CM: Transcription factors in long-term memory and synaptic plasticity. Physiol Rev. 2009; 89(1): 121-45.

PubMed Abstract | Publisher Full Text

36. Hinks GL, Shah B, French SJ, et al.: Expression of LIM protein genes Lmo1, Lmo2, and $\mathrm{Lmo3}$ in adult mouse hippocampus and other forebrain regions: differential regulation by seizure activity. J Neurosci. 1997; 17(14): 5549-59. PubMed Abstract

37. Altman J, Das GD: Autoradiographic and histological evidence of postnatal hippocampal neurogenesis in rats. J Comp Neurol. 1965; 124(3): 319-35. PubMed Abstract | Publisher Full Text

38. Guéneau G, Privat A, Drouet J, et al:: Subgranular zone of the dentate gyrus of young rabbits as a secondary matrix. A high-resolution autoradiographic study. Dev Neurosci. 1982; 5(4): 345-58.

PubMed Abstract | Publisher Full Text

39. Eckenhoff MF, Rakic P: Nature and fate of proliferative cells in the hippocampa dentate gyrus during the life span of the rhesus monkey. J Neurosci. 1988; 8(8): 2729-47.

PubMed Abstract

40. Gray WP, Sundstrom LE: Kainic acid increases the proliferation of granule cell progenitors in the dentate gyrus of the adult rat. Brain Res. 1998; 790(1-2): 52-9.

PubMed Abstract | Publisher Full Text

41. Wenzel HJ, Woolley CS, Robbins CA, et al:: Kainic acid-induced mossy fiber sprouting and synapse formation in the dentate gyrus of rats. Hippocampus. 2000; 10(3): 244-60.

PubMed Abstract | Publisher Full Text

42. Lein ES, Zhao X, Gage FH: Defining a molecular atlas of the hippocampus using DNA microarrays and high-throughput in situ hybridization. J Neurosci. 2004; 24(15): 3879-89.

PubMed Abstract | Publisher Full Text

43. Dong $\mathrm{H}, \mathrm{Csernansky} \mathrm{CA}$, Goico $\mathrm{B}$, et al:: Hippocampal neurogenesis follows kainic acid-induced apoptosis in neonatal rats. J Neurosci. 2003; 23(5): 1742-9. PubMed Abstract

44. Okazaki MM, Evenson DA, Nadler JV: Hippocampal mossy fiber sprouting and synapse formation after status epilepticus in rats: visualization after retrograde transport of biocytin. J Comp Neurol. 1995; 352(4): 515-34. PubMed Abstract | Publisher Full Text

45. Smith BN, Dudek FE: Short- and long-term changes in CA1 network excitability after kainate treatment in rats. J Neurophysiol. 2001; 85(1): 1-9.

PubMed Abstract
46. Parent JM, Yu TW, Leibowitz RT, et al.: Dentate granule cell neurogenesis is increased by seizures and contributes to aberrant network reorganization in the adult rat hippocampus. J Neurosci. 1997; 17(10): 3727-38. PubMed Abstract

47. Jiang M, Lee CL, Smith KL, et al:: Spine loss and other persistent alterations of hippocampal pyramidal cell dendrites in a model of early-onset epilepsy. J Neurosci. 1998; 18(20): 8356-68.

PubMed Abstract

48. Ribak CE, Navetta MS: An immature mossy fiber innervation of hilar neurons may explain their resistance to kainate-induced cell death in 15-day-old rats. Brain Res Dev Brain Res. 1994; 79(1): 47-62.

PubMed Abstract | Publisher Full Text

49. Cornejo BJ, Mesches MH, Coultrap S, et al: A single episode of neonatal seizures permanently alters glutamatergic synapses. Ann Neurol. 2007; 61(5): 411-26.

PubMed Abstract | Publisher Full Text

50. Cross DJ, Cavazos JE: Synaptic reorganization in subiculum and CA3 after early-life status epilepticus in the kainic acid rat model. Epilepsy Res. 2007; 73(2): 156-65.

PubMed Abstract | Publisher Full Text | Free Full Text

51. Gray WP, May K, Sundstrom LE: Seizure induced dentate neurogenesis does not diminish with age in rats. Neurosci Lett. 2002; 330(3): 235-8.

PubMed Abstract | Publisher Full Text

52. Bender RA, Dubé C, Gonzalez-Vega R, et al:: Mossy fiber plasticity and enhanced hippocampal excitability, without hippocampal cell loss or altered neurogenesis, in an animal model of prolonged febrile seizures. Hippocampus. 2003; 13(3): 399-412.

PubMed Abstract | Publisher Full Text | Free Full Text

53. Liu H, Kaur J, Dashtipour K, et al.: Suppression of hippocampal neurogenesis is associated with developmental stage, number of perinatal seizure episodes, and glucocorticosteroid level. Exp Neurol. 2003; 184(1):196-213. PubMed Abstract | Publisher Full Text

54. Watanabe Y, Johnson RS, Butler LS, et al.: Null mutation of c-fos impairs structural and functional plasticities in the kindling model of epilepsy. J Neurosci. 1996; 16(12): 3827-36.

PubMed Abstract

55. Kashani AH, Qiu Z, Jurata L, et al.: Calcium activation of the LMO4 transcription complex and its role in the patterning of thalamocortical connections. J Neurosci. 2006; 26(32): 8398-408. PubMed Abstract | Publisher Full Text

56. Pennypacker KR, McMillian MK, Douglass J, et al:: Ontogeny of kainate-induced gene expression in rat hippocampus. $J$ Neurochem. 1994; 62(2): 438-44. PubMed Abstract | Publisher Full Text

57. Tauck DL, Nadler JV: Evidence of functional mossy fiber sprouting in hippocampal formation of kainic acid-treated rats. J Neurosci. 1985; 5(4): 1016-22 PubMed Abstract

58. Represa A, Jorquera I, Le Gal La Salle G, et al.: Epilepsy induced collateral sprouting of hippocampal mossy fibers: does it induce the development of ectopic synapses with granule cell dendrites? Hippocampus. 1993; 3(3): 257-68.

PubMed Abstract | Publisher Full Text

59. Lynch M, Sutula T: Recurrent excitatory connectivity in the dentate gyrus of kindled and kainic acid-treated rats. J Neurophysiol. 2000; 83(2): 693-704. PubMed Abstract

60. Perez Y, Morin F, Beaulieu C, et al:: Axonal sprouting of CA1 pyramidal cells in hyperexcitable hippocampal slices of kainate-treated rats. Eur J Neurosci. 1996; 8(4): 736-748. PubMed Abstract | Publisher Full Text

61. Lee SK, Pfaff SL: Synchronization of neurogenesis and motor neuron specification by direct coupling of bHLH and homeodomain transcription factors. Neuron. 2003; 38(5): 731-45. PubMed Abstract | Publisher Full Text

62. Xu B, Li S, Brown A, et al:: EphA/ephrin-A interactions regulate epileptogenesis and activity-dependent axonal sprouting in adult rats. Mol Cell Neurosci. 2003; 24(4): 984-99.

PubMed Abstract | Publisher Full Text

63. Chen HH, Schock SC, Xu J, et al.: Extracellular ATP-dependent upregulation of the transcription cofactor LMO4 promotes neuron survival from hypoxia. Exp Cell Res. 2007; 313(14): 3106-16. PubMed Abstract | Publisher Full Text

64. Nair A, Vadodaria KC, Banerjee SB, et al:: Stressor-specific regulation of distinct brain-derived neurotrophic factor transcripts and cyclic AMP response element-binding protein expression in the postnatal and adult rat hippocampus. Neuropsychopharmacology. 2007; 32(7): 1504-19. PubMed Abstract | Publisher Full Text 


\section{Open Peer Review}

\section{Current Peer Review Status:}

\section{Version 1}

Reviewer Report 28 March 2014

https://doi.org/10.5256/f1000research.1764.r4163

(C) 2014 Leung S. This is an open access peer review report distributed under the terms of the Creative Commons Attribution License, which permits unrestricted use, distribution, and reproduction in any medium, provided the original work is properly cited.

\section{Stan Leung}

Department of Physiology and Pharmacology, University of Western Ontario, London, ON, Canada

The authors showed field-specific changes in expression of LIM-HD genes $L h \times 1, L h \times 2$, and $L h \times 9$, LIM-only gene Lmo4, and cofactor Clim1a in the adult hippocampus at 6 hours after seizure induction by kainic acid. No significant changes in expression were observed after seizure induction with the same dose of kainic acid in rat pups of postnatal day 7 (P7).

The subfield-specific changes in expression after kainic acid seizures were clearly presented for different members of the LIM-HD/ LIM-only family of transcription factors. This work extends previous studies that showed seizure-induced changes in expression of LIM-only genes in adult rats. The lack of expression change in $\mathrm{P} 7$ rat pups may be related to the lack of seizure-induced structural plasticity in immature animals, i.e., lack of cell death, mossy fiber sprouting and neurogenesis. Members of the LIM-HD family of transcription factors are necessary for different aspects of the development of the hippocampus. Thus, the changes in these transcription factors after seizures in adult rats may be related to seizure-induced neural plasticity, such as axon sprouting, progenitor proliferation, and changes in neuronal cell survival.

The central question of whether LIM-HD/ LIM-only transcription factors are causally related to the neural plasticity induced by kainic acid seizures remains unanswered. Are transient changes in these transcription factors, at $\sim 6$ hours after seizures, sufficient or necessary for the structural changes induced by kainic acid seizures? The design of the present study does not allow the consequences of kainic acid seizures to be studied, and not all adult rats induced with kainic acid seizures showed plasticity to the same extent. In fact, whether seizures are essential for the expression changes is not totally clear. In other studies, a single dose of kainic acid (intraperitoneal $10 \mathrm{mg} / \mathrm{kg}$ ) may not induce seizures in all adult rats, and the $10 \mathrm{mg} / \mathrm{kg}$ i.p. given to P7 rats was $>5$ times the dose needed for seizures as reported by Lynch et al. (Eur J Neurosci, 2000) . The authors should provide some justification of the kainic acid dose used, in terms of seizure induction in their adult and $\mathrm{P} 7$ rats.

"Regulation" in the title apparently means "changes in expression" rather than better control or lack of control of the genes and cofactors. 
The results are presented in an organized manner.

I would prefer to see the sample sizes (Ns) in the figure legend rather than in the "Quantitation and data analysis" section.

The issue of whether seizures are necessary and sufficient for the expression changes can be further discussed. Perhaps other molecules implicated for seizure-induced plasticity, e.g., neurotrophins, should be mentioned.

Overall, the experimental study appears to be well done.

Competing Interests: No competing interests were disclosed.

I confirm that I have read this submission and believe that I have an appropriate level of expertise to confirm that it is of an acceptable scientific standard.

Reviewer Report 11 October 2013

https://doi.org/10.5256/f1000research.1764.r2010

(C) 2013 Chen B et al. This is an open access peer review report distributed under the terms of the Creative Commons Attribution License, which permits unrestricted use, distribution, and reproduction in any medium, provided the original work is properly cited.

\section{Bin Chen}

Molecular, Cell, and Developmental Biology, University of California Santa Cruz, Santa Cruz, CA, USA

\section{Matthew Eckler}

University of California at Santa Cruz

Lakhina et al. examine the effect of chemically induced seizure on the expression of Lim family members and their cofactors, specially within the rodent hippocampus. Using in situ hybridization to measure mRNA levels they demonstrate that transcription of Lim, Lmo and Clim family members is altered in a field-specific manner specifically in adult but not early postnatal (P7) rats. These interesting observations extend previous work on seizure induced changes in Lmo1-3 expression (Hinks et al.) and raise several important questions for future study:

1. How rapid and persistent are the changes in gene expression following kainic acid administration?

2. Do alterations in gene expression drive physical remodeling within hippocampal neurons or vise verse?

3. Are there field specific differences in the timing of transcriptional changes?

4. What are the functional consequences of these transcriptional changes? 
5. It is interesting that changes in transcription were observed in adult but not juvenile animals, whose circuits generally believed to be more plastic. Might these transcriptional changes be a means by which to counteract decreasing circuit plasticity in adults?

Competing Interests: No competing interests were disclosed.

We confirm that we have read this submission and believe that we have an appropriate level of expertise to confirm that it is of an acceptable scientific standard.

The benefits of publishing with F1000Research:

- Your article is published within days, with no editorial bias

- You can publish traditional articles, null/negative results, case reports, data notes and more

- The peer review process is transparent and collaborative

- Your article is indexed in PubMed after passing peer review

- Dedicated customer support at every stage

For pre-submission enquiries, contact research@f1000.com 